\title{
PROXIMATE AND ACCEPTABILITY OF INSTANT PREKESE AND GARDEN EGGS COMPOSITE POWDER AS A THICKENER FOR SOUPS AND SAUCES
}

\author{
John Adanse ${ }^{1}$, Christina Akua Abi Atingah ${ }^{1}$, Simon George Wombosie ${ }^{2}$, Akua Serwah ${ }^{2}$, Kangi Vivian \\ Vonayire ${ }^{3}$ \\ 1, 1,2 Department of Hospitality Management, Bolgatanga Polytechnic, P. O. Box 767, Bolgatanga, \\ Upper East Region, Ghana \\ ${ }^{2}$ Aduman Senior High School box SE 983, Suame Kumasi, Ghana \\ ${ }^{3}$ Bawku Senior High School, Box 50, Bawku-Ghana
}

Abstract - Garden eggs-Prekese instant powder was developed by the combination of Prekese powder at $20 \%$ and $30 \%$. The garden eggs flour/powder was fortified with the Prekese powder which increased the level of protein $(\mathbf{1 1 . 4 0 \% )}$ of the composite powder produced from $\mathbf{7 0 \%}$ garden eggs powder and $\mathbf{3 0 \%}$ Prekese powder. It was much higher than that of $6.40 \%$ for product $A$, which comprised of $80 \%$ garden eggs powder and $20 \%$ Prekese powder. Fat content of the product labeled (A) was $18.30 \%$, and $4.80 \%$ for product $B$. It was observed that garden eggs composite flour produced from $80 \%$ garden eggs and $20 \%$ Prekese had the highest fat content than that of the Product B. The ash and carbohydrate content of the products were $5.70 \%$ to $6.30 \%$ of the total ash and $63.03 \%$ to $69.90 \%$ of the total carbohydrate. Data were analyzed into frequencies, percentages and cross-tabulation tables using Statistical Package for Social Solutions (SPSS 21.) The p-value was 000, implying that the difference in means is statistically significant at the $1,0.5$ and 0.1 levels. Sample B (70\% Garden eggs and 30\% Prekese) was least preferred in terms of colour aroma and texture with a score of approximately 3.22. While sample A $(80 \%$ garden eggs and $20 \%$ Prekese) had the mean value of approximately 4.10 for overall acceptability. This indicates that Prekese powder could be used in the production of a quality thickener by substituting garden eggs powder up to $20 \%$ level in instant soup based powder without any effects on the sensory attributes of the product.

Key words: Prekese, Garden eggs, instant soup powder, sauces, thickener, fruits and Vegetables

\section{INTRODUCTION}

Garden egg (Solanum incanum) is one of the most important members of the genus Solanum cultivated in West Africa. The fruits are consumed fresh as a snack, or used in the preparation of stew and soups while the leaves are used for medicinal purposes in some communities [1]. The fruits are harvested at the physiological maturity (unripe) stage, but usually before seeds are fully matured. The development of this spiced 'instant garden egg powder' as a thickening agent is a way of preserving the fruit from its short term post-harvest losses [2].

Solanum incanum is domesticated in Ghana in plentiful supply by growers [3] and bears edible fruits which can be consumed raw or cooked, and can be eaten in combination with other fruits and vegetables [1]. The eggplant is a delicate perennial often cultivated as annual cash crop. Eggplant fruits are known for being low in calories and having a mineral composition beneficial for human health. Garden eggs are also a rich source of potassium, magnesium, iron, and calcium [4]. According to [5], the garden egg is known scientifically as "Solanum incanum" from the family "Solanaceae". The fruits are either egg or pearshaped, round or long and cylindrical depending on the variety. Most of the local types are white or red fruits. They often grow up to 80 to $90 \mathrm{~cm}$ in height. Much wide genetic diversity has been observed among the species within this genus; therefore they are very interesting for breeding programs of the economically important cash crops such as Garden Eggs. Garden eggplant is the name imitative from the shape of the fruits of some cultivars which are white and shaped like chicken eggs [6]. 


\section{International Journal of Engineering Applied Sciences and Technology, 2020 \\ Vol. 4, Issue 10, ISSN No. 2455-2143, Pages 19-26 \\ Published Online February 2020 in IJEAST (http://www.ijeast.com)}

Solanum incanum (Garden egg) is highly perishable vegetable that needs processing to expand its shelf life. The shelf life of a garden egg is one week depending on the prevailing temperature and humidity. It has to be consumed within two to three days once ripped [2]. Garden egg just like any other fruit do not last forever; they can be kept under room temperature for two to five days until ripe, one to two weeks once it is ripe in the refrigerator and ten to twelve months in the freezer. According to [7], vegetables are preserved in various ways to stop or slow down spoilage and to increase its shelf life. Several research studies conducted prove that, with increasing production, losses of vegetables are also increasing proportionately. Post-harvest losses of fruit and vegetables are found to be 25$50 \%$ [8]. Several technologies exist to address the loss of perishable products. The usual storage methods include storage at low temperature, storage in controlled atmosphere (CA) and storage in a modified atmosphere [9]. Nutritionally, garden eggs contain water $(92.5 \%)$, protein $(1 \%)$, fat $(0.3 \%)$, and carbohydrates $(6 \%)$ [10], they provide between $30 \%$ and $50 \%$ of iron and vitamins in resource poor diets [11].

Prekese (Tetrapleura tetraptera) is used as a spice in Ghana. The fruit is used as seasoning in the preparation of soups and sauces as well as in the preparation of jam [12]. According to [13], the fruit is used to prepare soup especially from the first date of birth to prevent post-partum contraction. This attribute has been associated to the high concentration of iron in the dry fruit to regenerate lost blood [14]. The Akans use the fruit in treating hypertension and diabetes as a traditional medicine [15]. Prekese has been known as a medicinal plant in Africa for periods; the therapeutic properties of the plant have been recognized since 1948 and authenticated in laboratory and field experiments [16]. It could be found in all over West Africa, from Ghana to Senegal to Sudan, Uganda and Kenya, South to Angola and Tanzania. The tree grows best in secondary forests and rainforests, but is also found in savannah woodlands and rarely in African plains as well. Prekese (Tetrapleura tetraptera) encompasses variable quantities of nutrients, like protein, lipids and minerals, which are equivalent with some prevalent spices, such as red pepper, onion, curry and ginger, therefore it used as spice to replace imported spices in meat products may not affect customer acceptance [17], [18]. [19] opines that losses of perishable fruit and vegetables can be due to different factors along the supply chain. For instance, losses for the garden egg fruit can largely be attributed to bruising, water loss and compositional changes. The use of chemicals to ripen fruit has been connected with the high rates of loss for these vegetables [20]. Lack of appropriate storage facilities is seen as a factor that contributes to both losses of fruit and vegetables [20]. Reducing crop loss and waste by improving the supply chain will low Food loss in developing countries tends to occur more as a result of agricultural and infrastructural inefficiencies: therefore, it is harder to reduce food loss in such countries. Upon this background that the study is conducted to find out about consumers' acceptability of Instant Prekese and Garden Eggs composite Powder as a Thickener for Soups and Sauces

\section{METHODOLOGY}

The fresh samples garden eggs powder were prepared at the Food production laboratory of Hotel, Catering and Institutional Management before sending the samples to Kwame Nkrumah University of Science and Technology, Food Microbiological laboratory for the proximate composition.

\section{Sources of Raw Materials}

The Raw materials such as Garden eggs was bought from a farm gate at Sumbrungu, a suburb of Bolgatanga whereas the Prekese was also purchased from Kumasi Central Market.

\section{Samples Preparation Garden Eggs}

The green the garden egg and Prekese were washed with distilled water to remove any germs and particles. The two ingredients were cut into desirable sizes for the preparation of the thickener (instant Garden Eggs Powder). The garden eggs were divided into two; one part blanched and oven dried at $60{ }^{\circ} \mathrm{C}$ and left overnight whilst the remaining part was cut and sun-dried in its raw form. The product was sampled in two forms. Sample A was dried using the sun and the B using oven. The sun-dried sample was done in its raw form for two days, whiles the ovendried sample was par-boiled (blanched) before drying. After blanching, the vegetable was made to dry in the oven at a temperature of about 140 degrees Celsius for approximately 30 minutes. The samples were separately using Philip's blender 


\section{International Journal of Engineering Applied Sciences and Technology, 2020 \\ Vol. 4, Issue 10, ISSN No. 2455-2143, Pages 19-26 \\ Published Online February 2020 in IJEAST (http://www.ijeast.com)}

\section{Prekese}

The Prekese was washed and cut to desired sizes. The first sample was made to dry by sunlight within 28 degrees Celsius minimum at 45 degree maximum for a period of 48 hours. The second sample B, was made to dry in an oven for 140-150 degrees to achieve consistent oven temperature of $140^{\circ} \mathrm{C}$. It was then pounded in a cleaned mortar before blending to obtain the powdered product. It was further sifted to get the smooth powder.

\section{Garden eggs powder formulation}

The primary formulations used for making the instant garden eggs powder is mentioned in table 1. The garden eggs powder was prepared with the combination of Prekese powder (PP) in $20 \%$ and $30 \%$ respectively. After the drying process was done, the product was blended into powdered form. Samples of the finished product were used in preparing the soups. We added protein (fish, meat, etc) as desired; the powdered product $20 \mathrm{~g}$ of Prekese powder to $80 \mathrm{~g}$ of garden egg powder and $30 \mathrm{~g}$ of Prekese powder to $70 \mathrm{~g}$ of garden egg powder were thoroughly mixed separately with water and then poured over the steamed protein. Other ingredients for soup were added. The finished soups accompanied pounded fufu for consumers' to eat and assess the characteristics of the soups for their taste, aroma, colour, texture and nutritional contents.

Table 1: Formulation of instant garden eggs powder

\begin{tabular}{|l|l|l|}
\hline \multirow{2}{*}{ Ingredient } & Sample A (Raw and Sun Dried) & Sample B (Blanched and Oven Dried) \\
\cline { 2 - 3 } & Measurement & Measurement \\
\hline Garden eggs & $80 \mathrm{~g}$ & $70 \mathrm{~g}$ \\
\hline Prekese & $20 \mathrm{~g}$ & $30 \mathrm{~g}$ \\
\hline Salt & $2 \mathrm{~g}$ & $2 \mathrm{~g}$ \\
\hline Powdered pepper & $1 \mathrm{~g}$ & $1 \mathrm{~g}$ \\
\hline Powdered Onions & $3 \mathrm{~g}$ & $3 \mathrm{~g}$ \\
\hline
\end{tabular}

Formulation of Composite Flour and other Ingredients for biscuits Production

Two different samples of garden eggs and Prekese powder was produced and coded as A and B. The garden eggs sample (A) containing raw and Sun Dried Garden eggs and Prekese were produced using $80 \%$ garden eggs powder and 20\% Prekese powder whilst sample (B) which comprised of blanched and oven dried garden eggs and Prekese were formulated in the ratio 70: 30

\section{Proximate composition}

Total Carbohydrates, Total Ash, Crude Fiber, Crude

Fat, Protein and Moisture Content were determined using AOAC [21].

\section{Sensory Evaluation of the Product}

Fifty (50) respondents were chosen using the simple random sampling method from Bolgatanga Polytechnic for sensory analysis of the product. Each analysis was provided with set of Questionnaire (Sensory Ballot Sheet) and coded samples of A (Raw Sun Dried) and B (Blanched Oven Dried. The respondents independently answered the questions on the ballot sheet. The spiced garden egg powder was developed on a pilot base. The product was analyzed by caterers, food production lecturers and catering students, their comments and suggestions were used to modify the procedure before the final products were developed. The samples of the powder were taken to a food Microbiological laboratory at the Kwame Nkrumah University of Science and Technology (KNUST) to ascertain the nutritional compositions of the two products.

\section{Data Analysis}

Responses obtained from respondents were analyzed to make meaning from them. The data obtained from respondents were analyzed using independent t-test to compare two products in other to find out whether which of the two products were preferred by consumers with the aid of the Statistical Package for Social Science (SPSS) software, version 20 and Microsoft Excel. This software was used to save time since a manual analysis of the responses obtained took a lot of time). It was further opined that a standard survey usually have a confidence level of 
International Journal of Engineering Applied Sciences and Technology, 2020

Vol. 4, Issue 10, ISSN No. 2455-2143, Pages 19-26

Published Online February 2020 in IJEAST (http://www.ijeast.com)

$95 \%$ and margin of error of $5 \%$. The sample size was

calculated using the [23] model.

\section{ANALYSIS AND DISCUSSIONS}

Analysis of Demographic Data about respondents

Table 2: shows the cross-tabulation between gender and age of the respondents

\begin{tabular}{lcllll}
\hline & \multicolumn{3}{l}{ age of the respondent } & Total \\
\hline \multirow{3}{*}{$\begin{array}{l}\text { gender of } \\
\text { respondent }\end{array}$} & $18-24$ & $25-30$ & $31-36$ & \\
Total & 2 & 3 & 3 & 8 \\
The male & female & 34 & 8 & 0 & 42 \\
\hline
\end{tabular}

On demographic data, questions were asked on gender and age of the respondents.

females and 8 males. The majority of female The population size of 50 respondents was gathered from Sumbrungu Community, Bolgatanga. In dealing with gender and theirs ages, the respondents were 42 respondents were in the aged ranged of 18-24 and their counterparts males were in the ages between 1824.

Table 3: shows the cross-tabulation between gender and marital status of the respondents

\begin{tabular}{llllll}
\hline & \multicolumn{4}{l}{ marital status of the respondent } & Total \\
\hline \multirow{3}{*}{ gender of the respondent } & Married & widowed & No response \\
& male & 3 & 4 & 1 & 8 \\
Total & female & 35 & 7 & 0 & 42 \\
& & 38 & 11 & 1 & 50 \\
\hline
\end{tabular}

From table 3, 35 female respondents were married at the time of the study; 3 males' participants were also married at the time of the study; 7 females' participants were widowed. It is clear from the results that majority of the females participants were married at the time of the study.

Table 4: Proximate composition of samples

\begin{tabular}{|l|l|l|l|l|l|}
\hline Samples & MOISTURE \% & CRUDE ASH \% & FAT \% & PROTEIN \% & $\begin{array}{l}\text { TOTAL } \\
\text { CARBOHYDRATE } \\
\text { \% }\end{array}$ \\
\hline A & $6.70 \pm 0.11$ & $5.7 \pm 0.30$ & $18.2668 \pm 5.7$ & $6.4 \pm 0.40$ & $63.03 \pm 6.50$ \\
\hline B & $7.80 \pm 0.30$ & $6.30 \pm 0.01$ & $4.80 \pm 2.50$ & $11.40 \pm 0.30$ & $69.9 \pm 2.6$ \\
\hline
\end{tabular}

The moisture levels increased from $6.70 \%$ and $5.70 \%$ for product $\mathrm{A}$ and $\mathrm{B}$ respectively. The increased in the moisture level of product A may be as a result of increased in Garden eggs powder which was incorporated with the Prekese powder. The proteins content of the products ranged from $6.40 \%$, (sample A) to $11.40 \%$ (sample B). The increase in protein content could be as a result of increase in the level of substitution with Prekese powder. The ash content of the garden eggs-Prekese thickener increased from 6.30 to $5.70 \%$ with increase in the substitution of Prekese powder. The increase in the ash content could make the product a good source of minerals.
Fat content increased with increase in replacement percentage of garden eggs with Prekese powder. In $80 \%$ garden eggs powder, the fat content was $18.30 \%$, as against $4.80 \%$ for garden eggs flour blends of 80:20 and 70:30 respectively. The observation indicated that, the sample (A) had the highest fat content which could be as a result of garden eggs flour combination. The total carbohydrate contents and energy values increased progressively from $63.03 \%$ (sample A) to $69.90 \%$ (sample B). This increased in carbohydrate could be attributed to the decrease in the levels of garden eggs powder added. These differences may be due to recipe formulation and methods of preparation. 


\section{Analysis of Sensory Evaluation Test}

This is where two recipes were formulated and used in the preparation of two different types of soups for consumers' to taste and fill in the ranking scale provided to them. The data obtained from respondents were analyzed using independent t-test to compare two products in other to find out whether which of the two products were preferred by consumers. The tabulation considered the situations where respondents preference of the products available and their respective colour, taste, mouth feel and flavour.

Table 5: shows the summary statistics of the two products

\begin{tabular}{llllll}
\hline PRODUCT & product A & 196 & 4.10 & 1.047 & .075 \\
& Product B & 196 & 3.22 & 1.380 & .099
\end{tabular}

This output from table 5 shows that the average numbers of respondents that preferred product $\mathrm{A}$ was 4.10 versus 3.22 consumers for product $B$ with their

Table 6: shows the independent t-test output of the two products

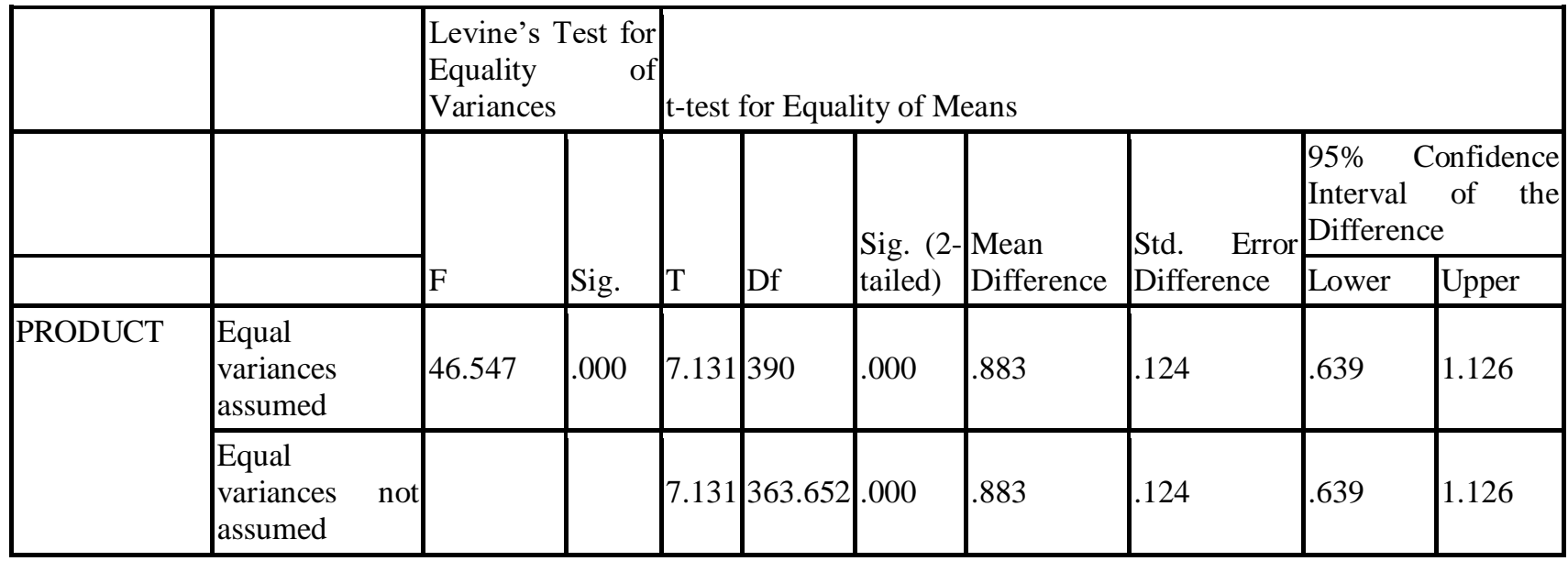

*. The mean difference is significant at the 0.05 level.

associated standard deviations of 1.047 and 1.380 consumers.
We used the second row since we almost never had any reason to think a priority that the amount of variation within each group will be the same. In the table 6 , it shows that the p-value is .000 , implying that the difference in means is statistically significant Table 7: shows the cross-tabulation between gender and which of these soup base samples do you prefer the most of the respondents.

\begin{tabular}{lllllll}
\hline \multirow{3}{*}{ gender of the respondent } & & product A & Product B & Not sure & No response \\
& male & 5 & 2 & 1 & 0 & 8 \\
Total & female & 32 & 8 & 0 & 2 & 42 \\
& & 37 & 10 & 1 & 2 & 50 \\
\hline
\end{tabular}

at the $.1, .05$, and .01 levels. This implies that product A was most preferred to consumers rather than product $\mathrm{B}$ since it has a mean of 0.883 higher than product $\mathrm{B}$.

\begin{tabular}{|c|c|c|c|c|c|c|c|}
\hline & \multicolumn{7}{|c|}{ please state your reason for your choice in q1 } \\
\hline & colour & appearance & aroma & flavor & taste & Nutrients & Total \\
\hline which of these soup product $A$ & 8 & 2 & 15 & 1 & 12 & 1 & 39 \\
\hline $\begin{array}{l}\text { base samples do you Product B } \\
\text { prefer the most }\end{array}$ & 1 & 1 & 3 & 1 & 4 & 1 & 11 \\
\hline
\end{tabular}




\begin{tabular}{|c|c|c|c|c|c|c|c|}
\hline & please : & tate your reason $\mathrm{fc}$ & or your c & e in $\mathrm{q} 1$ & & & \\
\hline & colour & appearance & aroma & flavor & taste & Nutrients & Tot \\
\hline which of these soup product $A$ & 8 & 2 & 15 & 1 & 12 & 1 & 39 \\
\hline $\begin{array}{l}\text { base samples do you Product B } \\
\text { prefer the most }\end{array}$ & 1 & 1 & 3 & 1 & 4 & 1 & 11 \\
\hline Total & 9 & 3 & 18 & 2 & 16 & 2 & 50 \\
\hline $\begin{array}{l}\text { From table } 7 \text {, it is clea } \\
\text { participants preferred produ } \\
\text { respondents indicated prod } \\
\text { opted for product B. T } \\
\text { preferences are subjectiv } \\
\text { individual consumers will }\end{array}$ & $\begin{array}{l}\text { that ma } \\
\text { A to pr } \\
\text { ct } A \text { and } \\
\text { is result } \\
\text { in natl } \\
y \text { all mea }\end{array}$ & $\begin{array}{l}\text { jority of the } \\
\text { duct B as } 37 \\
10 \text { consumers } \\
\text { implies that } \\
\text { re and that } \\
\text { ns have their }\end{array}$ & $\begin{array}{l}\text { nee } \\
\text { acc } \\
\text { pre } \\
\text { tas } \\
\text { var } \\
\text { tas }\end{array}$ & $\begin{array}{l}\text { regardi } \\
\text { bility. } \\
\text { d produ } \\
\text { th few r } \\
\text { reasons } \\
\text { d nutrien }\end{array}$ & $\begin{array}{l}\text { taste, } \\
n \text {, majc } \\
\text { because } \\
\text { dents p } \\
\text { as colc }\end{array}$ & $\begin{array}{l}\text { na and } \\
\text { of the co } \\
\text { ts aroma a } \\
\text { ing product } \\
\text { ppearance, }\end{array}$ & $\begin{array}{l}\text { over: } \\
\text { sume } \\
\text { d ni } \\
\text { B wi } \\
\text { lavou }\end{array}$ \\
\hline $\begin{array}{l}\text { Table 8: shows the cross-t } \\
\text { of the respondents }\end{array}$ & ulation $b$ & etween gender an & ad whic & hese sc & se san & o you le & \\
\hline & & $\begin{array}{l}\text { which of these } \\
\text { least prefer }\end{array}$ & soup ba & amples & & & \\
\hline & & product A & & t B & Total & & \\
\hline gender of the respondent & male & 1 & 7 & & 8 & & \\
\hline & female & 13 & 2 & & 42 & & \\
\hline Total & & 14 & 3 & & 50 & & \\
\hline
\end{tabular}

Respondents were asked which of the soups based samples do they least prefer. Out of a total number of 50 respondents, 36 indicated product $\mathrm{B}$ and 14 of the respondent cited product $\mathrm{A}$. The results further revealed that majority of the consumers least preferred the product $\mathrm{B}$ with the explanation that product B was heavy, having dull colour and pungent flavour.

Table 9: shows the cross-tabulation between which of these soup based samples do customers least prefer and reason for their choice

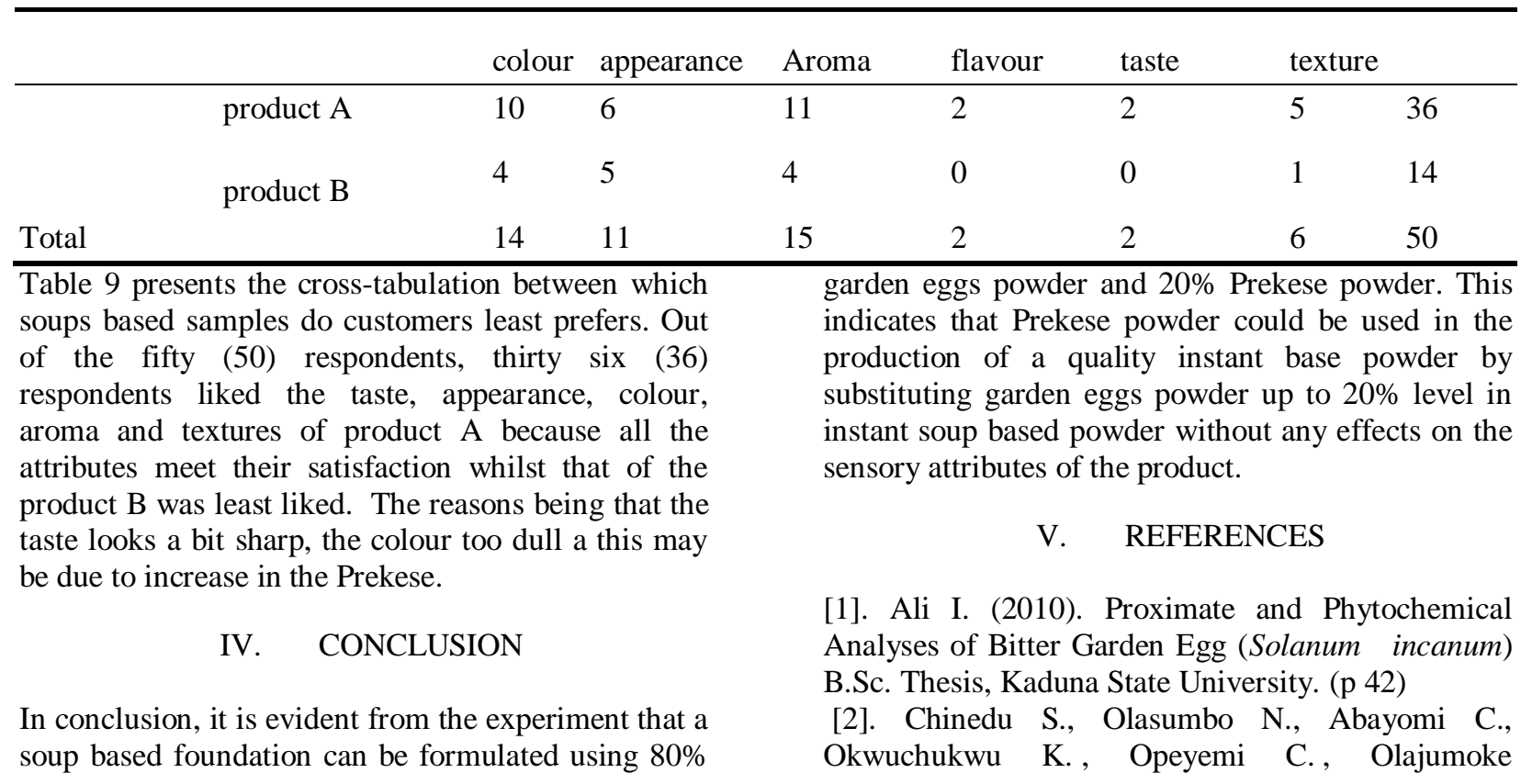




\section{International Journal of Engineering Applied Sciences and Technology, 2020 \\ Vol. 4, Issue 10, ISSN No. 2455-2143, Pages 19-26 \\ Published Online February 2020 in IJEAST (http://www.ijeast.com)}

K. and Damilola I. (2011). Proximate and Phytochemical Analyses of Solanum aethiopicum L. and Solanum macrocarpon L. Fruits. Research Journal of Chemical Sciences, 1(3), (Pp 63-71)

[3]. Danquah, J. A. (2010). Variation and correlation among agronomic traits in garden egg (Solanum gilo Raddi). B.Sc. Dissertation. Department of Crop Science, College of Agriculture and Consumer sciences, University of Ghana Legon-Accra, Ghana,

[4]. Zenia, M., and Halina, B., (2008). Contents of micro elements in eggplant fruits depending on Nitrogen and plant training method. J. Elementol 13 (2), (Pp 269-274),

[5] Aziz K. A., (2010). The effects of poultry manure and npk fertilizer on hydrological and physical properties, growth and yield of garden eggs (solanum melongena) in a sandy soil. kwame nkrumah university of science and technology, kumasi college, [6]. Ozobia A.P., Omaliko E.P, Amusa A. R., and Idacheba, N. (2013). Assessment of garden egg production in Giri town, Gwagwalada Area Council, Federal Capital Territory, Abuja, Nigeria. Scholarly Journal of Agricultural Science, 3 (4), (142-148)

[7]. Joy P. P., and Abraham M. (2013). Fruits, Benefits, Processing, Preservation and Pineapple recipes. Kerala India: Pineapple research station, Kerala Agricultural University,

[8]. Barbosa G., Gadelha F., Kublik N., Proctor A., Reichelm L., Weissinger E., Halden R. (2015). Comparison of Land, Water, and Energy Requirements of Lettuce Grown Using Hydroponic vs. Conventional Agricultural Methods. International Journal of Environmental Research and Public Health, 12(6), (Pp6879-6891) http://doi.org/10.3390/ijerph120606879

[9]. Hassan M.d.K.,, Lal Das Chowdhury B., and Akhter N. (2010). Post-Harvest Loss Assessment: A Study to Formulate Policy for Loss Reduction of Fruits and Vegetables and Socioeconomic Uplift of the Stakeholders

[10]. Esa Abiso N. S. (2015). Effect of Storage Methods and Ripening Stages on Postharvest Quality of Tomato (Lycopersicom Esculentum Mill), 16(November), (Pp127-137).

[11]. Pessarakli M. M., and Dris R. (2013). Pollination and nutritional composition of eggplant. Journal of Food, Agriculture and Environment 2(11), (Pp218-219)

[12]. Sabo E., and Dia Y. Z. (2009). Awareness and Effectiveness of Vegetable Technology Information packages by vegetable farmers in Adamawa State, Nigeria. African Journal of Agricultural Research, vol. 4 (2). (Pp 065- 070)

[13]. Darkwa S., (2013). Spices and condiments in Ghana; their utilization in comminuted meat products. Asian Journal of Agricultural and Rural Development 3 (12), (Pp899-908).

[14]. Aladesanmi A.J., (2007). Tetrapluera tetraptera: Molluscidal activity and chemical constituents. African Journal of Traditional, Complementary and Alternative Medicine 4 (1), (Pp23-36)

[15]. Uyoh E.A., Ita E.E., and Nwofia G.E. (2013). Evaluation of chemical composition of Tetrapluera tetraptera (Schum and Thonn.) Taub accessions from cross river state, Nigeria. International Journal of Medicine and Aromatic Plants Vol. 3 No. 3, (Pp386394).

[16]. Caroline A., and Busia K., (2005). An exploratory study of practice of herbal medicine by Akan people of Ghana. Alternative Medicine Review Vol.10 No. 2, (Pp112-122)

[17]. Oteng-Amoako A.A., Zuercher E., Abbiw D.K., Osie-Agyekumhene I., and Rogenmoser C. (2000). Description of 100 tropical African timber trees in Oteng-Amoako, A. (Eds.), 100 tropical African timber trees in Ghana; Tree description and wood identification with notes on distribution, ecology, silviculture, ethnobotany and wood uses. Department of Publishing Studies. Kwame Nkrumah University of Science and Technology, Kumasi. Ghana,

[18]. Akin-Idowu P.E., Ibitoye D.O., Ademoyegun O.T., and Adeniyi O.T., (2011). Chemical composition of the dry fruit of Tetrapleura tetraptera and its potential impact on human health. J. Herbs Spices Med. Plants, 17, (Pp52-61)

[19] Abugri D.A., and Pritchett G. (2013). Determination of chlorophylls, carotenoids and fatty acid profiles of Tetrapleura tetraptera seeds and their health implication. J. Herbs Spices Med. Plants, 19, (391-400)

[20] Kamrul -Hassan, M. et al. (2010). Post-Harvest Loss Assessment: A Study to Formulate Policy for Loss Reduction of Fruits and Vegetables and Socioeconomic Uplift of the Stakeholders USAID Report, Bangladesh,

[21] Hassan M.K, Chowdhury B.L.D, and Akhter N., (2012). Post-Harvest loss assessment: A study to formulate policy for loss reduction of fruits and vegetables and socioeconomic uplift of the stakeholders, NFPCSP, Retrieved from: http://www.nfpcsp.org/agridrupal/content/post-

harvestloss-assessment-study-formulate-policy-lossreduction-fruits-and-vegetables

[22]. AOAC (2004). Official method of Analysis of the Association of official Analytical chemists. 15th Ed., Washington. USA.

[23]. Sekaran U. and Bougie R. (2010). Research methods for business, a skill- building approach, $\left(6^{\text {th }}\right.$ ed.) New York: Wiley 


\section{ACKNOWLEDGMENT}

1. Mr. J. Adanse is currently working as a Lecturer in the Department of Hospitality Management at Bolgatanga Polytechnic, Ghana. He has completed his Master of Technology degree at University of Education Winneba under the discipline of Hospitality and Catering Management

2. Madam C. A Atingah is a Senior Lecturer at Bolgatanga Polytechnic, Ghana. She belongs to the Department of Hospitality Management and has completed her Master of Technology degree at University of Education Winneba under the discipline of Hospitality and Catering Management

3. Mr. S. G Wombosie is a part-time Lecturer in the Department of Hospitality Management, Bolgatanga Polytechnic, Ghana. He has completed his Master of Technology degree at University of Education Winneba under the discipline of Hospitality and Catering Management

4. Madam A. Serwah is a Home Economics Tutor in the Department of Home Economics, Aduman Senior High School, Ghana. She has completed her Master of Technology degree at University of Education Winneba under the discipline of Hospitality and Catering Management

5. Madam V. $\mathrm{K}$ Vonayire is a Home Economics Tutor in the Department of Home Economics, Bawku Senior High School, Ghana. She has completed her Master of Technology degree at University of Education Winneba under the discipline of Hospitality and Catering Management 